\title{
THEORETICAL ANALYSIS OF FACTORS AFFECTING THE DEVELOPMENT OF LOGISTICS CENTRE
}

Nadina Moroza ${ }^{1}$, Mg.sc.ing.; Inguna Jurgelane-Kaldava ${ }^{2}$, Dr.oec.

${ }_{1,2}$ Riga Technical University

\begin{abstract}
Profitable logistics complex system is an important factor for stable growth in economics of the state. Efficient management is the key to success, especially in logistic sector. To achieve great success in logistics it is decisive to understand and analyse all factors which influence on development of current sector. The aim of the present study was to review scientific literature about the factors affecting development of logistics centre. Furthermore, the sustainability construction qualitative analysis method was employed as basis to conduct the research. Based on the literature, authors defined different factors influencing on the development of logistics centre and conducted groups of factors. Using qualitative analysis, the author developed main factors and elaborated definitions for each factor to provide information about included sub-factors. Service level was indicated as one of the important categories. It shows level of clients' satisfaction with service given by the logistic centres. Finally, all factors were ranged by importance, to show gradation and influence on development.
\end{abstract}

Key words: logistics; development; warehouse; transport infrastructures.

JEL code: $\mathrm{O} 18$

\section{Introduction}

The interest to develop the logistic infrastructure worldwide has been growing very fast during the recent years, particularly due to more flexibility and availability of different transportation types.

Transport and telecommunication infrastructures play a key role for regional logistics development. A logistics chain manages the material flow of raw materials to final customers, covering many sectors such as transport, telecommunications, warehousing, customs, and developing logistics zones. Better logistics systems can attract direct foreign investment, which is widely regarded as an important economic growth engine (Carlucci et al., 2018).

Transporting of goods and any production of raw materials in the logistic chain is not possible without the necessary concentration of the stock in a fastened location and storing goods in relevant warehouses. All logistic processes increase the total value of goods. Because of that, work of the warehouses has a significant impact on the transporting of materials, all vehicles and turnover costs.

According to Dablanc (2013), some warehousing activities which were previously performed as part of a manufacturing or distribution activity (and on the same premises), have been outsourced to logistics providers, automatically increasing the number of warehouses. In some cases, manufacturers have implemented a specific warehousing/logistics facility when previously logistics functions (which required less space) were performed within the manufacturing facility itself. On the other hand, Fechner (2017) holds the view that, that the accessibility and the quality of the transport infrastructure [transport network] was another important factor, taking into account by investors and as the consequence also by developers during choosing the warehouse localization due to the fact, that it is correlated with the speed and reliability of logistics service and its costs.

Different factors can affect development of logistic centres, thus the author needs to take into account opinions of different papers and compare them. One of the main obvious factor is location of the logistic centre, therefore other sub-factors should be evaluated.

The problem of logistics centre location is an example of a multi-dimensional problem. These dimensions include accessibility, quality of transportation and infrastructure, and multi-modal transportation availability, which all influence the decision. Non-spatial factors also need to be 
considered, such as demographics, labour availability, and the volume of international trade in determining convenient areas for the new facilities (Onden, Acar \& Eldemir, 2016).

In the authors opinion, logistics centres are needed in different places of the cities, not only at the place where production plants are located. For deeper analysis it is necessary to explore all possible factors, which affects and are common to development of logistics infrastructure. Research object is Logistics centres and subject of research is factors which affect development of logistic centre. The main goal of the article is to present the result of analysis related to the defined factors for possible development of logistic centres. The research question provides a focus for this study: Which factors affect the development of logistics centres? Authors defined tasks to fulfil this study: theoretical analysis of factors and setting one clear group of factors which affects development of logistics centre. Authors used summative content analysis for defining categories. This study can be used as a theoretical base for development of logistics centre. Authors used different scientific databases for literature research.

The methods applied. Within the research, the authors used a summative content analysis method for defining categories and sub-categories, after that one common list of factors where defined.

Content analysis is a widely used qualitative research technique. Rather than being a single method, current applications of content analysis show three distinct approaches: conventional, directed, or summative. The major differences among the approaches are coding schemes, origins of codes, and threats to trustworthiness. A summative content analysis involves counting and comparisons, usually of keywords or content, followed by the interpretation of the underlying context (Hsieh \& Shannon, 2005).

Most important - to start searching for the right literature; therefore, were used different databases like Ebscohost, Web of Science, ResearcGate and Scopus. Most important searching words were: logistics centres, development, factors, warehouse.

Articles were chosen by conformity to research question and exploring field. After that these articles were re-checked and authors chose 31 papers, which were close to this research question.

In many articles these factors were mentioned more than once, so it was easy to understand authors' view on this question. In this case these factors were used more than once from one author. All citations got coding and were analysed during this research.

\section{Research results and discussion}

After exploring the field, the authors decided to research more those factors which influence development of logistics centres. Therefore, research question was defined: Which factors affect the development of logistics centres?

Weng (2016) explains, that in the past, companies only considered quality, costs, flexibility, and time in the measurement of performance, and environmental factors were not part of the mix. But twice he noticed that green environmental warehousing strives to reduce environmental pollutions, cargo spoilage, and transportation costs.

Jardas, Dundovic \& Badurina-Tomic (2016) states that city logistics can be defined as the process of optimizing the logistics and transport activities of individual companies in an urban area, respecting traffic, environmental and energy factors, and the respective organization of existing urban transport mechanisms in place. Shin \& Shim (2013) explains that failures of data warehouse projects are not only due to technological problems, but also due to the lack of consideration on managerial and 
environmental factors, such as characteristics of host organizations, top management support, and end users.

Gorecka \& Maksymiuk (2015) insist, that for private entrepreneurs it is necessary to have ability to cooperate with the administration and local government units, ecological and environmental factors, legal and financial factors. In the case of the private sector, the most important aspects are the economic and technical conditions of a given location, which include: the value of the logistics market, investment attractiveness for potential clients, availability of a multi-branched logistics and communications infrastructure, availability and price of land.

Table 1

\section{Analysis of factors}

\begin{tabular}{|c|c|}
\hline Reference & Factors \\
\hline (Abdullayev et al., 2016) & transport network \\
\hline (Alibone, 2011) & IT system \\
\hline (Anastase, 2013) & relationships between countries \\
\hline (Bisenieks \& Ozols, 2010) & costs; service \\
\hline (Braganca, 2008) & infrastructure; competitors \\
\hline (Dablanc, 2013) & process changes; location \\
\hline (del Rio Vilas, Longo \& Monteil, 2013) & human factors \\
\hline (Demyanova et al., 2017) & infrastructure \\
\hline (Devangan, 2016) & planning; location; transport network \\
\hline (Drelichowski \& Sikora, 2017) & IT system \\
\hline (Durmus \& Turk, 2014) & costs; transport network (3); good workers \\
\hline (Fechner, 2017) & transport network; service; costs \\
\hline (Gorecka \& Maksymiuk, 2015) & $\begin{array}{l}\text { location; value of logistic market; investment; price of land; } \\
\text { environmental; financial; legal }\end{array}$ \\
\hline (Grossea et al., 2014) & human factors; errors \\
\hline (Heitz, Launay \& Beziat, 2019) & transport network; service \\
\hline (Jardas, Dundovic \& Badurina-Tomic, 2016) & transport network (2); costs; service; environment \\
\hline (Jumaniyazov, 2010) & location; service \\
\hline (Kabashkin, 2007) & transport network; government \\
\hline (Karkh, 2016) & costs \\
\hline (Kucheruk \& Bozhok, 2016) & technologies; IT system \\
\hline (Mitropoulos et al., 2016) & existing trends; employment growth \\
\hline (Muha, Sever \& Sokolovskij, 2018) & flow of goods; number of transport companies; tax system \\
\hline (Onden, Acar \& Eldemir, 2016) & accessibility; quality; infrastructure; transport network \\
\hline (Onstein, 2015) & $\begin{array}{l}\text { costs (2); service; product demand ( } 2) \text {; lead-time; delivery } \\
\text { frequency; product characteristics }\end{array}$ \\
\hline (Onstein, van Damme \& Tavasszy, 2019) & $\begin{array}{l}\text { demand characteristics; service level ( } 3 \text { ); costs ( } 3 \text { ); product } \\
\text { characteristics ( } 2 \text { ); trade-off; demand level; land availability; } \\
\text { accessibility; government }\end{array}$ \\
\hline (Shin \& Shim, 2013) & management; environment; size of organization \\
\hline (Tartavulea, Belu \& Dieaconescu, 2011) & economic crisis \\
\hline (Turguttopbas, 2016) & costs; centralization; infrastructure; technologies; social \\
\hline (Voorhees, 1976) & transport network \\
\hline (Wagh, 2019) & costs; service level \\
\hline (Weng, 2016) & quality; costs; flexibility; time; environment (2) \\
\hline
\end{tabular}

Source: created by the authors

Costs' factors are described by such authors as Onstein, van Damme, Tavasszy, Wagh, Durmus, Turk, Turguttopbas, Fechner, Bisenieks, Ozols, Jardas, Dundovic, Badurina-Tomic, Karkh and Weng. 
Wagh (2019) explains that the basic aim is to minimize the total cost of operation, and storage while providing the desired level of service.

Other authors emphasize the importance of the transport network factor. Kabashkin (2007) stated that one of these efforts is the development of logistics centres (LCs) and their networking, which will continue to have an impact on improving communication links, spatial planning practices and approaches, logistics chain development and the promotion of sustainable transport modes. Heitz, Launay \& Beziat (2019) agree, that there is the importance of proximity to transport infrastructure, and more specifically to road infrastructure. Accessibility is a key factor in the location of logistics facilities.

Different point of view is expressed by authors who describe more human factors, tax system, social factors and economic crises. These authors are: Tartavulea, Belu, Dieaconescu, del Rio Vilas, Longo, Monteil, Grossea et al., Muha, Sever, Sokolovskij and Turguttopbas. Del Rio Vilas, Longo \& Monteil (2013) states that the lack of consideration of the human factors in production systems has negative direct consequences on labour work conditions and plant productivity.

From thirty-one (31) literature resources, authors got forty three (43) different coding of factors, which influence development of logistics centres.

Frequencies of categories

\begin{tabular}{|l|l|c|}
\hline Factors & Sub-factors from analysis & Frequencies \\
\hline Environment & Environment & 5 \\
\hline Costs & Costs & 12 \\
\hline Transport network & Transport network & 13 \\
\hline Service level & Service level, Service, Quality & 9 \\
\hline Organization infrastructure & $\begin{array}{l}\text { Employment growth, Size of organization, Infrastructure, } \\
\text { Management, Good workers, Number of transport companies }\end{array}$ & 6 \\
\hline Political issues & $\begin{array}{l}\text { Government, Relationships between countries, Social, } \\
\text { Economic crisis, Legal }\end{array}$ & 2 \\
\hline Human factors & Human factors & 6 \\
\hline Financial aspects & $\begin{array}{l}\text { Tax system, Value of logistic market, Financial, Investment, } \\
\text { Price of land, Land availability }\end{array}$ & 7 \\
\hline Technologies & IT system, Technologies, Process changes & 5 \\
\hline Time factors & Trade-off, Flexibility, Time, Accessibility & 6 \\
\hline Location & Centralization, Location & 7 \\
\hline Processing goods & $\begin{array}{l}\text { Demand characteristics, Delivery frequency, Errors, Lead time, } \\
\text { Flow of goods, Planning }\end{array}$ & 5 \\
\hline Market & Existing trends, Competitors, Product characteristics & 2 \\
\hline Product demand & Product demand & 6 \\
\hline
\end{tabular}

Source: created by the authors

Main factors are showed in Table 1, if one author used this factor more than once in his work, then it is written in the brackets how many times. It helped to illustrate the author's point of view. Gained factors were analysed and compared after that. This system allowed to elaborate group of main factors for development of logistic centre.

All factors were counted, thus initially the author defined the ones that were the most important and afterwards combined the other ones which were similar to each other. 
After combining these factors, authors highlighted fourteen (14) categories. Table 2 gives overview about all sub-factors, which were included during this study in the current category.

The most important factor of development of logistic centres is service level, which shows how productive each warehouse is working. For better analysis it is possible to see diagram of this research in Figure 1. This graph shows equal level of categories importance in one colour and are arranged by importance.

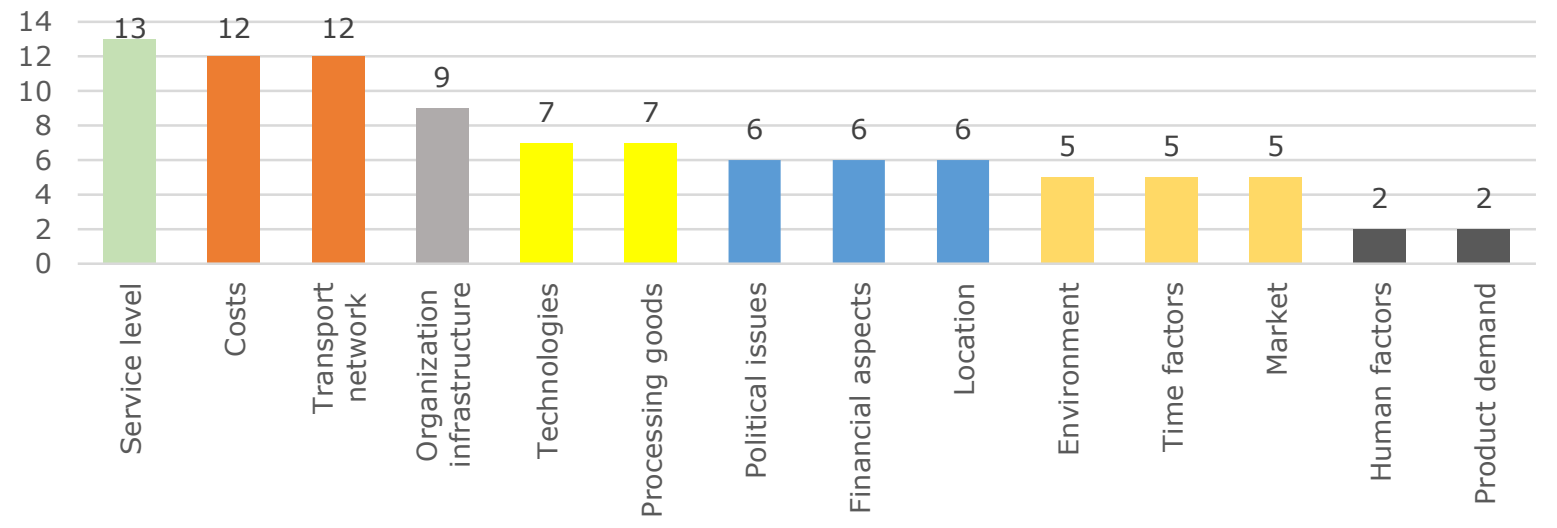

Source: created by the authors

Fig. 1. Frequencies by importance

In literature recourses, as most important factors were mentioned - service level, costs and transport network, followed by organization infrastructure, technologies and processing of goods.

Table 3

Definitions of elaborated factors

\begin{tabular}{|l|l|}
\hline Factor & \multicolumn{1}{|c|}{ Definition, sub-factors } \\
\hline Costs & Value of money which is spend on development of logistics centre and its facilities. \\
\hline Environment & $\begin{array}{l}\text { 'Green logistics'; all factors related to environmental issues and aspects, decreasing } \\
\text { air pollution and packaging recycling. }\end{array}$ \\
\hline Financial aspects & All coding's related to money and payment, investments etc. \\
\hline Human factors & Influence of people on different processes. \\
\hline Location & Place were logistic centre is located, accessibility and availability. \\
\hline Market & Market share of logistic. \\
\hline $\begin{array}{l}\text { Organization } \\
\text { infrastructure }\end{array}$ & Structure of the company, involved divisions in development of logistic centre. \\
\hline Political issues & Different governmental decisions, which can influence development of logistic centre. \\
\hline Product demand & Influence on development depending on product market share. \\
\hline Processing goods & Process of flow of goods in the company, inside processes. \\
\hline Service level & Providing the desired level of service to clients / cooperation partners. \\
\hline Technologies & IT and different innovations, which can be used in development of logistic processes. \\
\hline Time factors & $\begin{array}{l}\text { Definition of a time for any processes, which are related to development of logistic } \\
\text { centres. }\end{array}$ \\
\hline Transport network & Different transport noodles and accessibility from different types of transport. \\
\hline
\end{tabular}

Source: created by the authors

Author elaborated definition of all combined categories. It is illustrated in Table 3. Definitions give overview of all factors and define main ideas of each factor.

Not so important is any product related information or influence. Many large companies always think about transportation network, but not location. Nevertheless, cooperation partners always want to be near to biggest companies with whom they have largest goods' movement. Different groups 
think on various factors - for one it is more important to have a transport network near factory / logistics centre, for others - locations are more important than transportation network.

Five parts of the text showed environment as very important category of development in logistic field. From that perspective it is more important because of society and eco-friendly thinking. Not so important were human factors and product demand; nevertheless, we can 't ignore these factors. Many authors are thinking more about global issues, also these last five are also very important in development a logistic centre.

\section{Conclusions, proposals, recommendations}

1) Scientific and practicable literature provides a broad range of factors and ideas. The aim of article is reached by exploring different literature resources and established group of factors which influence the development of logistics centres.

2) Elaborated definitions give a quick overview about included sub-factors and allow to understand point of view and influencing area.

3) Frequencies of factors can be evaluated differently and can be used for exploring next steps of logistic centre sustainability in different places.

4) The results of the analytical study show that many factors are influencing each other and always are related with significant investments. Factors can be divided also by their importance for special groups - clients, partner, possible strategical partners, renters etc.

\section{Bibliography}

1. Abdullayev, S., Kiseleva, O., Adilova, N., Bakyt, G., \& Vakhitova, L. (2016). Key Development Factors of the Transit and Transport Potential Of Kazakhstan. TRANSPORT PROBLEMS 2016. Volume 11 Issue 2. 17-26. DOI: 10.20858/tp.2016.11.2.2.

2. Alibone, M. (2011). Critical Factors that Determine Picking Speed and Accuracy. Retrieved June 13, 2019, from https://www.logisticsmanager.com/page/3/?s=mike+alibon.

3. Anastase, I. (2013). Factors Affecting the Productive Potential of the Enterprise. SEA - Practical Application of Science. Romanian Foundation for Business Intelligence, Editorial Department, issue 1, 7-15.

4. Bisenieks, J., \& Ozols, E. (2010). The Problem of Warehouse Operation, its Improvement and Development in Company's Logistics System. Human Resources: The Main Factor of Regional Development. Issue 3, 206213.

5. Braganca, P. (2008). Fourth-Party Logistics - A study on modern logistics. Unpublished bachelor thesis, Umea School of Business and Economics, Umea University, Umea, Sweden.

6. Carlucci, F., Cira, A., Massari, S., Ioppolo, G., \& Siviero, L. (2018). Logistics and Land Use Planning: An Application of the ACIT Indicator in European Port Region. Land Use Policy. 75, 60-69. DOI: 10.1016/j.landusepol.2018.03.036.

7. Dablanc, L. (2013). 'Logistics Sprawl:' the Growth and Decentralization of Warehouses in the L.A. Area. 5th International Urban Freight Conference, 8-10 October 2013, (pp. 49-69). Long Beach, United States.

8. Del Rio Vilas D., Monteil, N.R., \& Longo, F. (2013). A General Framework for the Manufacturing Workstation Design Optimization: A Combined Ergonomic and Operational Approach. SIMULATION, 89(3), 306-329. DOI: $10.1177 / 0037549712462862$.

9. Demyanova, O., Zaidullina, C., Pugacheva, M.A., \& Girfanova, E.Yu. (2017). Innovative Infrastructure as the Factor Of Efficiency Increase Of Industrial Enterprises Activity. 4th International Multidisciplinary Scientific Conference on Social Sciences and Arts SGEM2017, 22-31 August 2017. (pp. 393-403), Albena, Bulgaria. DOI:10.5593/sgemsocial2017/13/S03.050.

10. Devangan, L. K. (2016). An Integrated Production, Inventory, Warehouse Location and Distribution Model. Journal of Operations and Supply Chain Management. Volume 9, Number 2, 17 - 27. DOI: 10.12660/joscmv9n2p17-27.

11. Drelichowski, L., \& Sikora, M. (2017). Factors Influencing the Development Of Virtual Food Supply Chains In Polish International Trade. Studies \& Proceedings of Polish Association for Knowledge Management. Issue 86, 5-12.

12. Durmus, A., \& Turk S.S. (2014). Factors Influencing Location Selection of Warehouses at the Intra-Urban Level: Istanbul Case. European Planning Studies. Volume 22, No. 2, 268-292. DOI: 10.1080/09654313.2012.731038.

13. Fechner, I. (2017). Economic and Logistic Conditions of the Warehouse Market in Poland. Scientific Journal of Logistics 'LogForum'. Issue 1/2017, article 9, 103-113. DOI: 10.17270/J.LOG.2017.1.9. 
14. Gorecka, A., \& Maksymiuk, M. (2017). Determining Factors of Logistics Centres Development in Poland. Logistics infrastructure. Volume 33, 61-68.

15. Grossea E., Glocka C., Jaberb M., \& Neumannb P. (2014). Incorporating Human Factors in Order Picking Planning Models: Framework and Research Opportunities. International Journal of Production Research. Vol. 53, No. 3, 695-717. DOI: 10.1080/00207543.2014.919424.

16. Heitz, A., Launay, P., \& Beziat, A. (2019). Heterogeneity of Logistics Facilities: an Issue for a Better Understanding and Planning of the Location of Logistics Facilities. Eur. Transp. Res. Rev. 11, 5. DOI: 10.1186/s12544-018-0341-5.

17. Hsieh, H-F., \& Shannon, S. (2005, November). Three Approaches to Qualitative Content Analysis. Qual Health Res. 15(9): 1277-88. DOI: 10.1177/1049732305276687.

18. Jardas, M., Dundovic, C., Badurina-Tomic, P. (2016). Supply Chain - a Key Factor of the Sustainable Development of City Centers. Scientific Journal of Maritime Research 30. 45-50.

19. Kabashkin I. (2007). Logistics Centres Development In Latvia. TRANSPORT - 2007. Vol XXII, No 4, $241-246$. DOI: $10.3846 / 16484142.2007 .9638135$

20. Jumaniyazov, N. (2010). Creating Multi-Modal Logistics Centers: Prospect for Development in Central Asia. Perspectives of Innovations, Economics \& Business. Volume 6, Issue 3, 21-23. DOI: 10.15208/pieb.2010.70.

21. Kucheruk, G., \& Bozhok, A. (2016). Factors of Logistics and Forwarding Service Formation and Development. Proceedings of the National Aviation University. 2016. N 2(67), 121-125. DOI: 10.18372/23061472.67.10441.

22. Mitropoulos, L., Adamos, G., Nathanail, E., Yatskiv, I., \& Kabashkin, I. (2016). Building on European Scientific Excellence to Develop an Educational Program on Intermodal Connections for Latvia and the Region. Transport. 79-93. DOI:10.3846/16484142.2017.1280851.

23. Muha, R., Sever, D., \& Sokolovckij, E. (2018). An Approach to the Location of a Warehouse Distribution Centre in the International Environment: a Slovenian Perspective. Scientific Journal Zeszyty Naukowe of the Maritime University of Szczecin. 79-85. DOI: 10.17402/304.

24. Onden, I., Avni Zafer, A., \& Fahrettin, E. (2016). Evaluation of the Logistics Center Locations Using a MultiCriteria Spatial Approach. Transport. 322-334. DOI: 10.3846/16484142.2016.1186113.

25. Onstein, S. (2015). Distribution Structure and Distribution Centre Location Decision-Making-a Review. Vervoerslogistiek Werkdagen, 26-27 November 2015. Breda, Netherlands.

26. Onstein A., Tavasszy L. \& A. van Damme D., (2019). Factors Determining Distribution Structure Decisions in Logistics: a Literature Review and Research Agenda, Transport Reviews, 39:2, 243-260. ISSN: 0144-1647 (Print) 1464-5327 (Online) Journal homepage: https://www.tandfonline.com/loi/ttrv20

27. Shin, YB., \& Shim, C. (2013). An Empirical Study of the Organizational Factors Affecting the Optimization of Data Warehousing Design Strategy. Franklin Business \& Law Journal, 141-160. DOI: 10.1080/17509653.2015.1113394.

28. Tartavulea, R. I., Belu, M.G., \& Dieaconescu, V. C. (2011). Spatial Modeling in Logistics Decision-Making Processes. Identifying the Optimal Location for a Single Central Warehouse. Annals of the University of Oradea, Economic Science Series. Vol. 20 Issue 1, 137-143.

29. Turguttopbas, N. (2016). Regional Development and Logistic Centers: A Turkish Experience. Perspectives of Innovations, Economics \& Business (Pieb). Volume 16, Issue 2, 89-103. DOI: 10.15208/pieb.2016.07.

30. Voorhees, R. (June, 1976). Communications: A New Logistics Factor in Location Decisions and Patterns of Regional and National Development. Transportation Journal. Vol. 15, No. 4, 73-84. Retrieved June 11, 2019, from http://www.jstor.org/stable/20712387.

31. Wagh M. (2019). Design of warehouse. Global Journal of Engineering Science and Research Management. 2(5), 1011-1014.

32. Weng C.K. (2016). A Study from Client's Perspectives on Exploring Financial Factors of Green Logistics' Development. International Journal of Performance Measurement. 2016, Vol. 6, No.1, 1-16.

33. Karkh D., (2016). Тенденции развития складскои недвижимости как фактора конкурентоспособности предприятий оптовои торговли (Trends in the development of warehouse real estate as a factor in the competitiveness of wholesalers). Upravlenec. Vol. 59, Issue 1, 81-84. (in Russian) 